\title{
English Communication Needs of Engineering Students
}

\author{
Dwi Poedjiastutie ${ }^{1, *}$, Lailatul Rifah ${ }^{2}$ \\ ${ }^{1}$ English Department, University of Muhammadiyah Malang, Malang, Indonesia \\ ${ }^{2}$ Language Centre, University of Muhammadiyah Malang, Malang, Indonesia
}

Email address:

dpoedjiastutie (a) yahoo.com (D. Poedjiastutie)

${ }^{*}$ Corresponding author

To cite this article:

Dwi Poedjiastutie, Lailatul Rifah. English Communication Needs of Engineering Students. International Journal of Language and Linguistics. Vol. 7, No. 2, 2019, pp. 69-77. doi: 10.11648/j.ij11.20190702.13

Received: February 18, 2019; Accepted: March 25, 2019; Published: April 22, 2019

\begin{abstract}
Oral communication is critical for engineer graduates to be more competitive in the work-places. In foreign and second language teaching, one of several consequences is the increasing importance attached to careful studies of learner needs as a prerequisite for effective course design. Therefore, the purpose of this study is to examine the oral communication needs of Civil Engineering students at UMM and so as to examine the challenges engineering students face to fulfill the needs. Qualitative research was employed in this study. Research of this type is always based on the voices and interpretations of the participants. Therefore, in this study, the ideas and perspectives of Civil Engineering students were constructed by following this approach. As in qualitative a theory was constructed from the new data rather than the old ones. The participants of this study were students of Civil Engineering Department who were enrolled in the sixth and eight semesters and attended the internship program in academic year 2017-2018. The research instruments used in this study are: Focus Group Discussion (FGD) and Web-based Survey. The finding showed that oral communication was strongly needed by the engineering students.
\end{abstract}

Keywords: Needs Analysis, Engineering Students, Communication, ESP, EFL Learners

\section{Introduction}

The environment in which most companies operate in nowadays is a highly competitive one and make them to have high standards when it comes to hiring employees especially those with multiple skills which includes English communication skills. According to Zedeck and Goldstein [1], communication skill is the first priority among other skills in hiring the employees. This is in line with the work of Zeigler [2] who stated that some employees will be hard to get a job due to their low level of competence in English, especially in oral English and that companies put more efforts in recruiting those staff that are ready to compete in the global market.

According to the study conducted by Adawiyah and Bambang [3], based on employers' perspective, English is very important when it comes to supporting their technical skill on their job. And in the declaration of ASEAN Economic Community (AEC) November 2007, the ASEAN countries have committed to developing the economic cooperation among themselves. Also, the ASEAN community put their economic foundation on five prominent elements which are: free flow of goods, services, investment, capital, and skilled labour so as to generate a single market among the ASEAN countries [4]. Along with an attempt to support the labour movement, the Ministers of Economy of ASEAN countries have expanded the service coverage into several areas like nursing, architecture, medical, accounting, and engineering. And Araminta and Halimi [5] reported that it was first adopted in the field of engineering.

According to Keliat, Virgianita, Banna, \& Aryanto [6], the level of English competence of Indonesian labors are still below the expected standard despite the fact that Indonesia was the largest labor contributor in ASEAN. A study conducted by Education First [7] explained that Indonesia was ranked $39^{\text {th }}$ of 80 countries they assessed with 52.15 scores of English proficiency and this has effect on the hiring process.

Like other professionals, the engineers are expected to possess a set of multidisciplinary and interpersonal skills in order to participate effectively in the business community [8]. This means that the $21^{\text {st }}$ century engineers should perform 
competitively well in the professional setting, communicate in English effectively, and be able to demonstrate high efficiency [9]. In the future, many companies will only employ those who are able to communicate in English [2]. In summary, oral communication is critical for engineer graduates to be more competitive in the work-places [10].

The importance of universities in shaping students for their future employment cannot be overemphasized. Therefore, the teaching of English should be an opportunity for the EFL students to learn and know the language. In recent years, many undergraduate courses in universities have provided English for Specific Purposes (ESP) which become one of the most prominent areas of EFL teaching. University of Muhammadiyah Malang (UMM), therefore, establishes ESP under the auspices of Language Centre (LC) UMM in order to help students to develop in oral English communication. All the freshmen from all faculties in UMM, including the civil engineering, are being given teaching of ESP for two semesters. However, the issue of communication competence in the professional workplaces remains a global concern for the engineers [11].

Different steps have been taken to improve the level of English competence of UMM students, including redesigning the English curriculum but there has been no systematic analysis of students' needs. Also, no tailored effort was made in the curriculum design or in the classroom instruction towards addressing the particular needs of those students. This means that a systematic and rigorous evaluation, including a needs analysis, needs to be conducted in order to improve the English curriculum and the raise the level of English language proficiency of the graduate students. And the use of such evaluation is supported in some literatures. Long [12] for instance, claims that "In this era of globalization, there are growing demands for accountability in public life, including in education. In foreign and second language teaching, one of several consequences is the increasing importance attached to careful studies of learner needs as a prerequisite for effective course design (p.1)”.

There is an urgent need for all courses to be relevant and to be seen to be relevant - to the needs of specific groups of learners and of the society at large. And at UMM, this includes a range of stakeholders like teachers and employers from all faculties. As Long [12] suggests, this can be achieved through an evaluation that includes a thorough needs analysis. This needs analysis (NA) has a vital role in the process of designing, developing and implementing the curriculum of any course, be it English for Specific Purposes (ESP) or general English courses or other courses [13-14].

According to Leki [15], English courses are more beneficial if the goals are beyond class assessment and extended towards the real and future needs of those learners and other stakeholders. Moreover, it is the existing institutions' responsibility (e.g., LC UMM) to anticipate the future needs of all stakeholders [16]. Collecting and analyzing data on the needs, will allow teachers to have an idea of the gap between what has been done and what needs to be done. Knowing how to close the gap helps to define the purpose of the next generation of educational services [17]. Accordingly, a NA can support the development and implementation of language policies at both macro and micro levels, with far-reaching consequences.

\section{The Role of Needs Analysis and Course Development}

According to Swales [18], ESP is one of the programs for developing the language competence of the students or meeting their goals as far as communication is concerned. Therefore, communicative competence becomes very important for ESP. Marwan [19], also reports that teaching English in Indonesian context is divided into two categories; English for General Purposes (EGP) and English for Specific Purposes (ESP). However, in reality, the implementation of ESP teaching focuses on combining both the general and specific purposes. This is supported by the statement of Yuwono and Harbon [20] that teacher qualification and teaching materials are the issues in teaching ESP. Similarly, Marwan [19] also found that institutions in Indonesia did not have enough quality materials for ESP teaching in order to support students' objectives of English learning.

Another issue of concern about ESP teaching was reported by Darjowijoyo [21]. He explained that most of ESP teachers in Indonesia have not mastered adequate vocabulary and gotten enough knowledge needed to teach students in those disciplines related to the subject and in fact, many have to withdraw from teaching it. This will contribute to the failure of the ESP program at the university and consequently the universities will not be able to equip and prepare their graduates to be ready for job competition. More so, Baso [22] stated that the inappropriate implementation of ESP teaching will bring a negative effect on the graduates when they are entering the workplaces. Hence, the purpose of teaching ESP in Indonesia should be reviewed in order to meet the standard of English for workplaces.

There was also a study conducted by Bhattacharyya [8] which focuses on how the graduates of engineering meet the standards of the future workplace environment in Malaysia. The study involves three different groups of participants: students, lecturers, and professional engineers. She found that the employees faced some challenges in terms of the mastery of both interdisciplinary and interpersonal competencies like teamwork, decision making and communication skills.

Also, Aramaninta and Halimi [5], found that the engineering faculty at Universitas Indonesia is enforced to establish English for Professional Purposes handled by both professional English teachers and engineering professionals to meet the needs of engineers in the ASEAN Economic Community. Questionnaires and the interviews were used to collect the data from the alumni, engineering students, the HRD (Human Resources Development) from the local company, head of departments and lecturers. This is motivated by the fact that engineers have to possess the 
English-communication skills. These skills are used as the main communication tools in ASEAN global market and in their partnership.

In Thailand, a study was conducted based on the huge difference between the needs of employers and the graduates' competence in oral communication. Jarupan [23], in that study, focuses on identifying the level of oral communication of Thai engineering students in Rajamangal University of Technology, Taiwan. He found out that there are different levels of students in oral communication competence which affect the teaching and learning process. And the study is expected to be one of the sources of the use of appropriate instruments for teaching and learning process on ESP theory so as to produce competent engineering graduates.

Conclusively, NA is a crucial step in understanding the communication needs of engineering students at UMM. Therefore, the purpose of this study is to examine the oral communication needs of Civil Engineering students at UMM and so as to examine the challenges engineering students face to fulfill the needs.

\section{Method}

\subsection{Research Design}

Qualitative research was employed in this study. Research of this type is always based on the voices and interpretations of the participants. Therefore, in this study, the ideas and perspectives of Civil Engineering students at UMM were constructed by following this approach. As in qualitative a theory was constructed from the new data rather than the old ones [24].

Contextualization of the data is another important aspect of this research. Thus, the data was interpreted only in the context of the UMM where it was collected. As a qualitative study, the concern is not about the generalization, but rather the accuracy and adequacy of the situation being studied.

\subsection{Participants}

The participants were made up of 117 students of Civil Engineering Department who were enrolled in the sixth and eight semesters and attended the internship program in academic year 2017-2018. This study analyzed the needs of oral English communication in the workplace based on their perspective that had been formed during the internship programs in several companies. The data assisted ESP teachers specifically and university to design an appropriate material for the Civil Engineering students.

Among the respondents, 83 amounting to $71 \%$, returned back the survey and this was accepted to represent the research subjects. According to Fincham [25], anything from $60 \%$ has fulfilled the minimum response's rates and in this situation, we have $71 \%$. Some of the participants were also invited for Focus Group Discussion (FGD)

\subsection{Research Instruments}

The research instruments used in this study are: Focus
Group Discussion (FGD) and Web-based Survey.

\subsubsection{Focus Group Discussion (FGD)}

In FGD, participants were selected using convenient sampling techniques. Convenience sampling is also known as availability sampling which is solely based on the participants' willingness to participate in the study [26]. In this technique, the participants were chosen without any particular requirements. And according to Saunders, Lewis, \& Thornhill [26], this sampling techniques help researchers in conducting short duration and low budget research. Also, Freitas [27] reports that FGD is a type of in-depth interview of a group in collecting data over a short period of time. And it usually gives rich results since participants could interact at the same time to deal with the same topic of discussion.

Knowing the proper number of people is very important in FGD. In recent times, many researchers tend to have six to eight people, while that was not so many years ago as it was between eight to ten people. When deciding the number of the participants in FGD, a researcher should consider the opportunity for each person to talk and voice their diverse perception [28, 29, 30, 31]. In this study, the researcher had two FGD with twelve participants in which each FGD engaged six people for 60 minutes.

Two FGD were chosen since saturation point was achieved. Saturation point is the point in the data analysis that shows no new information. It happens when the researcher found similar data over and over again. Then, he or she may continue to the analysis step [32]. Saturation point is a clear indication of the end of data collection [33]. In this FGD, the researcher used a video recorder to record all the activities, and it helped to store the information even though the researcher was moderating the discussion.

The researcher constructed semi-structured questions in order to obtain relevant data to this study. This was used in FGD session in order to gather deeper and richer information from the participants.

\subsubsection{Web-based Survey}

Web-based was also used to gather information for this research, especially for data triangulation of the previous finding in FGD. There were 20 number of questions in this survey using the Likert scale. All the 83 participants took part in it and it was used because there were many students who did their internship program outside of the city. The link to the survey was sent to their mobile WhatsApp application, and so it was easy for them to access and to fill in the required information.

According to Weber \& Bradley [34], collecting data through online media is less timely and needs limited cost. Several studies suggested that web-based surveys are more efficient and fascinating than traditional methods of survey in that the latter is hard to reach [35]. Because the internet users spread across different places, it is easier and faster to get the data from the participants who are far away from the researcher. The time allocated for the 20 web-based questions was 40 minutes. 


\subsection{Data Collection Procedure}

In this research, the iterative approach was used. This approach is the main process of collecting and recollecting data from different ways and connects them thereby leading

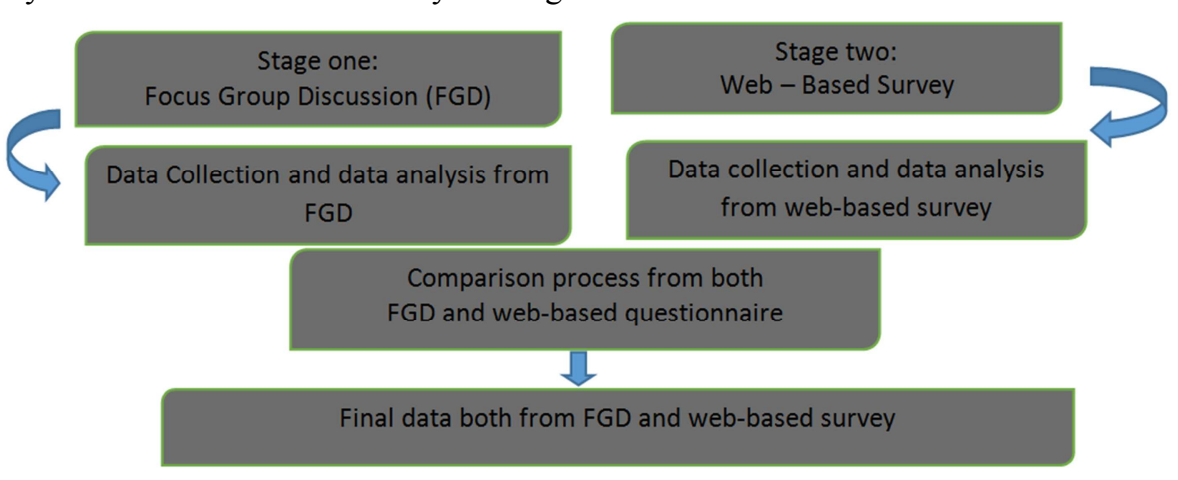

Figure 1. Data Collection Procedure.

\subsection{Data Analysis}

The researcher analyzed the data in several steps as explained below:

After transcribing the result of FGD, the researcher read the data over and over to get the initial impression. This is known as "Think aloud" process. At the same time, the researcher also removed unnecessary data. Data coding was done to know the classification and the emerging trends.

The survey results were calculated using Excel program in the form of percentage. Then comparison was done between the survey results and the emerging trends from the FGD before drawing conclusions.

\subsection{Trustworthiness}

The trustworthiness of this study was addressed in the two ways:

\section{(1) Credibility}

According to Lets et al. [37], the use of two or more data collection tools is one of the characters of credibility of a research. In this study, the researcher used FGD and validated web-based survey as the data collection tools.

(2) Confirmability

Confirmability is the research strategy used to avoid the subjectivity and bias in the data collection process through data tracking [38]. In this research, the researcher used video recorder to confirm, track, and clarify the neutrality of the data from the participants during the FGD session.

\section{Result and Discussion}

\subsection{The Needs of English as Requirement for Jobs}

Based on the FGD result, the participants mentioned that oral English communication is the first skill that should be mastered by the engineers

I think the most important skill is oral communication (speaking) compared with writing and reading. And now we are in internationalization era, so we have to follow the to the focus of the research [36]. The FGD was held at the first stage and then continued by the web-based survey. The figure below describes the process of data collection procedures.

rhythm. (AR-1.1)

This statement was supported by the data from the survey where 78 participants (94\%) out of 83 agreed that oral English communication was very important and needed in the workplace.

Students explained that both national and multinational companies required English certificate in the recruitment process. The English scores obtained from standardized test is considered to reflect the applicant's ability in the language.

I think, I really need English to support me in getting a good score in English test, such as TOEFL, TOEIC, IELTS, because all companies required the English certificate. So, for me the most important one is getting the highest score to fulfill the job requirements. (AF-3.7)

In the FGDs, students stated that the capability of mastering oral English communication will be the first consideration in the process of a job interview.

From the interview process, our English ability is rated as a job qualification. Interview will be our first step to go or stop the next process of requirement. The interviewer will directly assess our competence through direct conversation. Mastering hard skill does not guarantee a job, most of the companies tried to look for a good engineer who can perform both hard skill and soft skill very well. (AF-4.4)

This statement was also supported by the survey result where $76(92 \%)$ out of 83 participants admitted that oral English communication was crucial factor when attending a job interview.

a. The Needs of English for Job Contract

One of the participants stated that success in winning a job contract was the dream of almost all companies. Therefore, mastering oral English communication is required.

In my opinion, English is needed in winning the jobcontract, because in every work situation in Civil Engineering, started from winning the project. The project winners are the one who have a good idea in a good communication way. The projects are offered by not only local companies, but also international companies. As a consequence, we have to prepare our English communication 
skill. (RK-3.1)

Some participants in the FGDs session clearly stated that oral English communication helped the engineers to succeed in negotiating the job contract. Many of them said that working as an engineer, they needed to have the competence to negotiate in order to secure the project.

Currently, the most important thing in Indonesia is the ability to negotiate. Many projects are offered by other countries, so even we are good as engineers we also should have a good ability in English negotiation. If not, we will never win the project. (RG-3.4)

b. The Needs of English for professional functions

There is need for oral communication in order for the employers to carry out their professional activities such as meeting, discussion, presentation, and carrying out job instructions.

From the FGDs session, the participants stated that oral English communication was needed for the employee when they worked in a multinational company where the owner and the supervisors are usually from the English speaking countries.

The project owner in my internship place is a Singaporean, and the sub-contractors are Indonesians. In every meeting, English is the only language accepted. If we cannot speak English, we cannot work there. (IC-2.4)

This claim was supported by the survey where $65(78 \%)$ out of 83 participants admitted that oral communication helps the employee to participate actively in a meeting.

Based on the participants' answers during the FGD sessions, oral English communication was also used in some activities like discussion and during presentations. This was in line with the result of the survey where 78 (94\%) out of 83 participants expressed such opinion. The discussion and presentation sometimes was done using telephone or teleconference. One participant mentioned that English communication was used to communicate with the manager, supervisor, or even supplier from other countries audiovisually.

Telephone and skype are used by the employees when they are doing teleconference or update the information to the foreign manager, and of course they should speak English. (PR-3.10)

This statement was supported by the survey result in which 73 , that is, $88 \%$ of the participants agreed that oral English communication was needed to communicate with other people through telephone/video call. The respondents also explained that good English helps to avoid misunderstanding. Engineers have the possibility of destroying the company's reputation when they misunderstand the instruction given to them. This claim was from the FGD participants who emphasized that oral communication can affect the success or failure of projects.

Yeah...just imagine when the engineers misunderstand instruction from supervisor about the building coordinate, it can be very fatal. For example, when the supervisor instructed us to build the room in point A, but it was built in point $C$, it will make us rebuild according to the supervisor's will. It has happened many times due to a misunderstanding. (RK-3.2)

Another aspect that may cause misunderstanding are the technical terms. One of the participants mentioned that technical terms were used in most of the engineering work places every day and that the meanings of such terms were different from the General English (GE).

Knowing the technical terms in Civil Engineering is a must to avoid misunderstanding. For example, the word "slippery" in general meaning is "smooth so that it causes something to slide", but in technical terms means "pads”. (AG-6.2)

c. The Needs of English for casual conversation

Participants agreed that English was needed not only in the formal situation, but also in the day to day communication inside and outside of the workplace. They used it to communicate with other staffs at the same division, in their team, with supervisors, and even with the managers.

English is also needed when we are working with the foreign managers. In everyday communication in informal situation, we should perform very good skill in English both for technical and non-technical skills. (PR-3.10)

This assertion was supported by the survey results where $78(94 \%)$ out of 83 participants mentioned that English is needed to communicate easily with company owners, managers and supervisors in casual conversation and informal situation. However, none of the participants mention this in the survey.

d. The Needs of English for Job Promotion

One participant in the FGD tried to describe how oral communication could be very important in the workplace in helping them to get a better position. During his internship program, he discovered that many good positions were occupied by the employees who could perform very well in oral English communication.

I found some interesting cases when I joined internship in one of the multinational companies in regards to communication. Most of the people there (including manager, supervisor, administrator, and workers) use English as the communication tool. Having very good oral communication has also become one of the points to have promotion in the office. This is because in everyday meeting they should use English. I think I should improve my English if I want to apply in this company. (IC-3.8)

Another participant in the FGD stated that there were many top positions in engineering world managed by foreigners who usually won the project due to their ability in presenting their idea orally. Many Indonesian engineers were working as sub-contractors who are doing what the contractor (owner) wanted. Many great projects are executed by people from the foreign countries, this shows that the use of English is crucial.

In Indonesia, there are only 900 PMP (Project Management Professional) who hold international standard in Civil Engineering which is very small amount compared with the total number of engineers in Indonesia. To be PMP is very difficult because all the tests both soft skill and hard skill are using English. One of the PMP person said that oral 
English communication is one of the factors to success in the $P M P$ test. If the engineering graduates want to be PMP in the future, they have to study hard. (GB-3.9)

This explanation was supported by the survey result where $76(92 \%)$ out of 83 participants conceded that oral English communication has become one of the most influential aspects in upgrading position in any company.

To fulfil the needs of engineering students, this university should consider of eliminating these challenges. Those challenges have been mentioned by the respondents in this study. The following section discusses the challenges in more detail.

\subsection{The Challenge of ESP Teaching in Indonesia}

a. Teaching Capacity

During the FGD sessions, some participants indicated that ESP program was the same as GE because the teacher teaches from the same material in which the students had already learnt from during high school. Other participants argued that the teachers did not know what to teach the engineering students. This also led to an assumption that the teachers lacked of ability to select the appropriate teaching approaches and strategies including the materials, methods, and use of language.

I am very surprised when joining ESP class for two semesters. I felt that my English was getting lower than before. The teacher gave the same portion of English skill or even lower than it was in my high school. I also felt that the teacher did not have enough knowledge and vocabulary related to engineering subject, so they just gave general English to fulfill their job as teacher. (AF-4.1)

Another participant stated that the teaching performance in English for specific purposes did not meet his expectation. Thus, he felt disappointed.

In ESP class I had a big expectation. In the first meeting, the teacher said that in ESP class we will study more about English used in Civil Engineering, and I put my big expectation on it. Surprisingly, I did not get knowledge about Civil Engineering. (GB-5.3)

The other student said that:

Besides, I also find that the ESP classes are boring because the teaching activity is always the same from time to time. (PR-4.5)

In another FGD session, another participant suggested

For me, the teachers should be someone who knows about the departments. It will make them teach appropriately. We can learn general English by ourselves, but we do need someone to help us in our subject to support both our academic performance and workplace. (AF-4.4)

b. Teaching Approaches and Materials

From the FGDs session, most participants stated that ESP course was not different from general English course. But the students are expected to master those technical engineering terms that will help them in both their studies and their career.

Based on my experience in internship program, I totally did not get much understanding about the Civil Engineering. I remember when ESP teacher taught us the English for
General one, not focus on Civil Engineering. And now I can say "what does ESP mean?". I felt that we wasted our time for studying English, because I felt my English is very low. (RK-5.1)

Some other participants clarified that the meaning of ESP course did not reflect in the learning process. Some participants assumed that the teacher had lack of understanding of engineering so we did not discuss any issue in Civil Engineering.

One teacher is very good in understanding the Civil Engineering issue, but the other teachers never touch any issue related with my study, so I do not get much with my study in ESP class.

(AG-6.2)

Some participants in the FGD made suggestions to sum up their friends' idea about the ideal way of teaching ESP and also the appropriate teaching materials for Civil Engineering students.

In my first semester, my teacher was great and he helped me a lot to understand Civil Engineering, but in the second semester, the teacher was not competent and so I did not enjoy following his class (RK-5.1).

This was also supported by the survey data which showed only $10(12 \%)$ of 83 participants agreed that ESP teachers used appropriate materials that will allow the students to get certain things for their future use.

c. The Duration of ESP Courses

Students had different perspectives about this issue. A student specifically mentioned that time would not be a huge problem when the content of ESP classes is appropriate.

I think, the success of ESP courses is not about how long it will be, but how efficient is the learning process. I mean, the content should be relevant. If it is just one semester and the learning process is very effective and appropriate, it will be very good. (AF-6.4)

The duration of teaching ESP also affected its usefulness and effectiveness the courses. This statement was supported by $8(10 \%)$ out of the 83 that ESP program for two semesters was sufficient to prepare the students for the workplace.

The researcher found that Civil Engineering students had various opinions on the needs of oral English communication in preparing them for job recruitment, achieving their future career, and supporting them in some activities in their workplace such as for meeting, discussion, job-contract and in other professional functions. Some of their statements supported previous research as regards to the needs of oral communication in the workplace, while other statements were new and emerged from their experience while having their internship programs in places where they need English to negotiate and secure contract. However, many participants showed their dissatisfaction on the ESP courses offered by the university in terms of meeting their expectations and needs. Also, the teaching capacity of lecturers, teaching approaches and materials, and the duration of ESP courses were the three main causes of their dissatisfaction. Therefore, it can be concluded that the university, the Language Centre of UMM, has not yet addressed the complex communication needs. Its 
first priority is to improve the teaching capacity of the instructors such as their delivery skills, the skills of selection the appropriate ESP materials, and the course duration.

\subsection{Discussions}

Based on these findings, it is obvious that Civil Engineering students strongly agreed that oral English communication was a priority skill in supporting their academic success and in work situation especially in the ASEAN Economic Community era. The finding showed that oral communication was strongly needed by the engineering students at UMM. And this is similar to the findings of Zaid and Kamarudin [39], Kakepoto et al. [40], Bhattacharyya [8], Araminta and Halimi [5], Lan, Proust, and Lim, [41].

In the work of Zaid and Kamarudin [39], they were specifically looking at the needs of oral English communication from the final year of Engineering students in UTM Malaysia. According to the research, seven activities are needed in oral communication, and these include: making telephone conversation, delivering speech, giving instructions or briefings, external and internal meetings, presentations, and participating in seminars.

Kakepoto et al. [40] claimed that engineering students should develop their English communication skills such as those for oral presentation, meeting, discussion, conversation, and project participation. In addition, Bhattacharyya [8] reported that engineers need to master both interdisciplinary and interpersonal competence in order to be effective leaders in the global workplaces mainly in the area of teamwork, critical thinking, decision making, and communication skills. He underlined that the engineers need to master technical oral presentations in order to compete well in the $21^{\text {st }}$ century.

In their research, Araminta and Halimi [5] focused on analyzing the needs of engineering students at Universitas Indonesia with regards to the graduates' readiness in mastering English language skill to compete with other ASEAN graduates. They suggested that the oral communication skills which should be taught include: ability to speak in internship place, giving a feedback in a meeting, doing presentation, having phone calls, doing teleconference, and having intercultural communication or informal meetings. More so, Lan, Proust, and Lim [41] stated that interpersonal communication skills, teamwork skills and technical knowledge skills were the most important skills needed by engineers in their career development.

Apart from all these, there are some differences. First, there was new information about the oral communication needs of engineers in the workplace which has not been revealed by the previous researchers, that is, the needs of English for job contract and negotiation. From the FGD and survey results, it was found that the engineering students' need to master oral English communication as a tool that will help them in winning contracts. The participants reported that many of engineers could not win projects because they could not share their idea perfectly. And therefore, the need for mastering oral English communication. Another thing found in this research was the needs of oral English communication during negotiations. Engineers were required to master communicating in English so as to be able to get all the benefits of the project.

The second aspect is the fulfillment of Civil Engineering students' needs of oral communication in ESP courses. The purpose of offering ESP courses in UMM was to get students ready in this globalization era. And this is supported by Swales [18] who explained that ESP was one of the programs for developing students towards helping them to meet their needs in terms of communication. However, the purpose of ESP courses was in stark contrast with what is being taught or learnt in the classroom. Most of ESP teachers taught GE rather than ESP. And this is in line with the work of Araminta \& Halimi [5] which declared that the English teaching process in ESP program did not meet the students' English needs

The following are the reasons for students' dissatisfaction with ESP courses: low teaching capacity of ESP lecturers; teaching approaches and English materials which were not relevant to the students' needs; and the short duration of ESP courses. These findings are similar to other studies: Yuwono and Harbon [20], Marwan [19], and Darjowijoyo [21].

Considering all these, the participants recommended for the future improvement of ESP courses. Some suggested that teachers should at least have a basic background in engineering and hoped that these teachers were engineering who apart from knowing engineering terminologies, could also meet the students' needs. Others suggested that ESP teacher should not be changed, that is, the same person should take the courses in both semesters so as to avoid repeating the materials.

\section{Conclusions}

There are wide variety of students' English needs of communication. The researcher divided the importance of English oral communication for Civil Engineering students before obtaining a job in three categories: the needs of English for global competition; the needs of English for job requirements, and the needs of English for future career. Second, the researcher also differentiates the importance of English oral communication at the workplace into two main categories: (a) the needs of English for job promotion, and (b) the needs of English for professional functions. However, most of participants felt dissatisfaction on ESP courses offered by University to fulfill their needs. Participant clearly stated that ESP courses for two semesters were not enough to equip English, communication for the workplaces. Many participants said that they need to take another English preparation class before obtaining a job. In addition to the issue of the time-frame of ESP, the teaching capacity of ESP lecturers, inappropriate teaching approaches and inappropriate selection of materials, became their focus of dissatisfaction. Lack of English competence is the other reason why they need to take another English preparation class. They hope that ESP could be formulated as one of the preparation class to support them both in academic 
achievement and future career.

\section{References}

[1] Zedeck, S., \& Goldstein, I. L. (2000). Sliding bands: An alternative to top-down selection. In R. Barrett (Ed). Handbook of fair employment strategies. Westport, CT: Courum Books.

[2] Zeigler, R. (2007). Student perceptions of "Soft" skills in Mechanical Engineering. Proceeding of International Conference on Engineering Education - ICEE 2007. Coimbra, Portugal.

[3] Adawiyah, W. R., and Bambang, A. P. (2009). Scaling the notion of islamic spirituality in the workplace. Journal of Management Development, 36(7), 877 - 898.

[4] Hidayat, A. S. (2008). ASEAN economic community (AEC: Opportunities and challenges for Indonesia. Jurnal Ekonomi dan Pembangunan, 16 (2), 1-3.

[5] Araminta, L. D. W., \& Halimi, S. S., (2015). ASEAN Economic Community 2015: Needs analysis of Universitas Indonesia's engineering students. Indonesian Journal of Applied Linguistics, 5(1). 11-18.

[6] Keliat, M., Virgianita, A., Banna, S., Aryanto, A. (2013). Pemetaan Pekerja Terampil Indonesia dan Liberalisasi Jasa ASEAN. Jakarta: ASEAN Study Center UI \& Kementerian Luar Negeri RI.

[7] Valentina, J. (2017, December 13). Indonesia falls in 2017 English Proficiency Index. The Jakarta Post. Retrieved from: https://www.thejakartapost.com/life/2017/12/13/indonesiafalls-in-2017-english-proficiency-index.html

[8] Bhattacharyya, E. (2013). Walk the talk: Technical oral presentations of engineers in 21st century. Procedia- Social and Behavioral Science, 123, $344-352$.

[9] Eisner, S. (2010). Grave new world? Workplace skills for today's college graduates. American Journal of Business Education, 3(9), 27-50.

[10] Mills J. E., Treagust, D. F. (2003). Engineering education -- Is problem based on project-based learning the answer? Australasian Journal of Engineering Education, online publication 2003-04, 1-16.

[11] Rajala, S. A. (2012). Beyond 2020: Preparing engineers for the future. Proceedings of the IEEE 100 (Special Centennial Issue), $1376-1383$.

[12] Long, M. H. (2005). Second language needs analysis. Cambridge: Cambridge University Press.

[13] Hamp-Lyons, L. (2001). English for academic purposes. In R. Carter \& D. Nunan (Eds.), The Cambridge guide to teaching English to speakers of other languages (pp. 126-130). Cambridge: Cambridge University Press.

[14] Finney, D. (2002). The ELT curriculum: A flexible model for a changing English for Specific Purposes. In Richards, J. C. \& Renandya, W. A. (Eds). Methodology in language teaching: An anthology of current practice (pp. 69- 79). Cambridge: Cambridge University Press.

[15] Leki, I. (2003). Research insights on second language writing instruction (Publication no. EDO-FL-03-06). Available from ERIC Clearing House on Language and Linguistics Washington DC.

[16] Oliver, R., Grote, E., Rochecouste, J., \& Exell, M. (2012). Addressing the language and literacy needs of aboriginal high school VET students who speak SAE as an additional language. The Australian Journal of Indigenous Education 41(2), 1-11.

[17] McCawley, P. F. (2009). Methods for conducting an educational needs assessment: Guidelines for cooperative extension system professionals. Moscow: University of Idaho.

[18] Swales, J. M. (1992). Language for specific purposes. In W. Bright (Ed.). International encyclopedia of linguistics (2), 300-302. New York, Oxford: OUP.

[19] Marwan, A. (2009). ESP teaching challenges in an Indonesian vocational higher institution. The English Teacher, 38, 1-12.

[20] Yuwono, G., Harbon, L. (2010). English teacher professionalism and professional development: Some common issues in Indonesia. The Asian EFL Journal, 12 (3), 145-163.

[21] Darjowidjojo, S (2000). English teaching in Indonesia. EA Journal. 18 (1), 22-30.

[22] Baso, R. S. (2014). Exploring Indonesian graduates' English language skills and companies' English language skills requirements in East Kalimantan, Indonesia. IOSR Journal of Humanities and Social Science (IOSR - JHSS) 19 (6). 44-56.

[23] Jarupan, S. (2013). The English oral communication competency of Thai engineering students. International Journal of Scientific and Research Publication. 3 (3), 1-9.

[24] Erlandson, D. A., Harris, E. L., Skipper, B. L., \& Allen, S. D. (1993). Doing naturalistic inquiry: A guide to methods. Newbury Park, CA: Sage Publications.

[25] Fincham, J. E. (2008). Response rates and responsiveness for surveys, standards, and the journal. American Journal of Pharmaceutical Education 72 (2), 43.

[26] Saunders, M., Lewis, P., \& Thornhill, A. (2012). Research methods for business students. Pearson Education Limited.

[27] Freitas, H. (1998). The focus group, A qualitative research method: Reviewing the theory, and providing guidelines to its planning. Merrick School of Business, University of Baltimore (MD, EUA).

[28] Opphenheim, A. N (1992). Questionnaire design, interviewing and attitude measurement. London: Pinter.

[29] Krueger, R. A. (1994). Focus groups A practical guide for applied research (2nd ed.). Thousand Oaks, CA: Sage Publications.

[30] Morgan, D. L. (1998). Focus groups as the qualitative research. Thousand Oaks, CA: Sage Publications.

[31] Mattar, F. N (1999). Pesquisa de marketing: Metodologia, planejamento, vol. 1 (5ed.). Sao Paulo: Atlas.

[32] Seale C. (1999). Grounding theory. In Seale C, (ed). The quality of qualitative research. London: SAGE Publication Ltd.

[33] Carlsen, B., and Claire, G. (2011). What about N? A methodological study of sample-size reporting in focus group studies. BMC Medical Research Methodology, 11(26). 
[34] Weber, J., \& Bradley, K. D. (2006). Strengths and weaknesses of conducting web-based surveys: A review of the literature. Paper presented at the Mid-Western Educational Research Association annual meeting. Columbus, $\mathrm{OH}$.

[35] Lyons, A. C., Cude, B., Lawrence, F. C., \& Gutter, M. (2005). Conducting research online: Challenges facing researchers in family and consumer sciences. Family and Consumer Sciences Research Journal, 33(4), 341-356.

[36] Srivastava, P., \& Hopwood, N. (2009). A Practical iterative framework for qualitative data analysis. International Journal of Qualitative Methods, 8(1).

[37] Letts, L., Wilkins, S., Law, M., Stewart, D., Bosch, J., \& Westmorland, M., (2007). Guidelines for critical review form: Qualitative studies (Version 2.0). McMaster University, Hamilton.
[38] Bryman, A. (2015). Social research methods (4th ed.). Oxford: Oxford University Press.

[39] Zaid, Y, H. and Kamarudin, H. (2011). Oral communication needs of Mechanical Engineering undergraduate students in UTM: as perceived by the learners. UNSPECIFIED, 1-8.

[40] Kakepoto, I., Habil, H., Omar, N. A. M., Boon, Y., \& Hamdani, M. (2012). Oral communication skills of engineering students of Pakistan in perspective of industrial internship. International Journal of Applied Linguistics \& English Literature 1(2), 170-176.

[41] Lan, B., O. Proust, G., Lim, B. (2009). An empirical study of communication competence of civil engineering graduates Implication of engineering curriculums. Available at: http://docplayer.net/22612757-An-empirical-study-ofcommunication-competence-of-civil- engineering-graduatesimplication-of-engineering-curriculums.html. 